\title{
III. Selim'in Sanatçı Kişiliği ve Beste Formundaki Eserlerinin Usul-Aruz İlişkisi Yönünden İncelenmesi
}

\author{
Ayşe Emsal AKSIN ÇEVİK* (iD
}

ÖZ

Bu çalışma, Türk Musikisine damgasını vurmuş bir musikişinas ve bestekâr olan Osmanlı Padişahı Sultan III. Selim’in Türk Musikisindeki konumunu, musiki geleneğine etkileri ve söz konusu dönemindeki musiki hareketleri çerçevesinde ortaya koymayı ve Sultan III. Selim'in "Beste" formundaki eserlerini usul-aruz vezni ilişkisi yönünden inceleyerek, güfte, vezin ve beste uyumunu araștırmayı amaçlamaktadır. Selim reformcu karakterinin yanı sıra sanatçı kişiliği ve Türk musikisinde "Selim Dönemi”" olarak adlandırılacak derecede etkiye sahip bir isimdir. Bestelediği eserler ve terkip ettiği makamlar ile dönem sanatçıları üzerindeki etkisi ve himayesi ile Türk musikisinde verimli bir dönem yaratılmasına katkı sağlamıștır. Çalıșmada bestekârın "Beste" formundaki eserleri usul-aruz vezni ilişki açısından incelenmiştir. İnceleme amacıyla önce eserler yeniden yazılmış, sonra güftelerdeki hecelerin dağılımı, usulün velvelesi kullanılarak yapılmıștır. Mısra içerisindeki her hece bu darplara göre yerleștirilmiștir. Usul şablonları bilgisayar ortamında üç çizgi üzerinde yazılmış ve eserlerin güftesi nota değerlerine göre dağıtıllmıştır. Güfte ve vezin arasında bilinçli bir ilişkinin olup olmadığının görülebilmesi için musiki ve edebiyat ilişkisinin besteleme teknikleri arasında yer alması bakımından önemli olduğu düşünülmektedir. Bu doğrultuda çalışmada Selim’in Beste’lerinde usul-aruz vezni kullanımının belli bir tekniğe dayalı olarak bestelenip bestelenmediği araştırılmıştır. Araştırma bulguları bestekârın bestelerindeki usul -vezin ilişkisinin çoğunlukla zeminhâne ile uyumlu, meyan kısımlarının ise farklı yapılarda olduğunu göstermektedir.

Anahtar Kelimeler: beste formu, aruz vezni, aruz-vezin, III. Selim, Klasik Türk müziği, Türk müzik tarihi.

\section{An Examination of Selim III's Artist Personality and His Works Composed in the Form "Beste" in terms of the Relationship of the Pattern - Aruz Rhythm}

\begin{abstract}
This study aims to reveal the impact on Turkish music tradition and the position of Sultan Selim III, who was a music lover, composer, and performer who left his mark on Turkish music history, in Turkish Classical Music and to examine his works in the form of Beste in terms of the harmony of lyrics and the relationship of the pattern and the aruz rhythm. In this study, first of all, Selim III's position as a musician and composer in Turkish music and musical movements in his time have been investigated. Later, his works in written the form Beste were analyzed in terms of the pattern - the aruz rhythm. It is thought that the relationship between music and literature is important to see whether there is a conscious relationship between lyrics and the aruz rhythm. Accordingly, in this study, it was investigated whether the use of the pattern and the aruz rhythm in Selim III's Bestes was composed based on a certain technique. The research findings show that the relationship between the pattern and the aruz rhythm in the composer's Bestes is mostly compatible with zeminhâne, while the parts meyan have different structures. history.

Keywords: the form beste, aruz rhythm, the pattern and aruz relationship, Selim III, Turkish classical muic, Turkish music
\end{abstract}

\section{Giriş}

Osmanlı İmparatorluğu’nun tarih boyunca varlığını sürdürebilmesi, Türk kültür yapısını korumas1, bilimden sanata her alanda farklı kültürleri özümsemesi ve bir bileşke yaratması sayesinde olmuştur. Türk kültürü üç kıtaya yayılmış ve gelecek nesillere kültürel anlamda büyük bir miras bırakılmıstır. Devlet yönetiminde olsun ya da olmasın küçük yaşlardan itibaren musiki ve edebiyat gibi birçok alanda eğitim alan şehzadeler Osmanlı'nın eğitim ve sanata ne kadar değer verdiğinin göstergesi olmuştur. Böylece en iyi şekilde eğitim gören padişahlar hem kendi kişisel anlayış ve idare tarzlartyla imparatorluğun yönetiminde hem de edebiyat ve musiki başta olmak üzere padişahın ilgisi ve yeteneklerine bağlı olarak her alanda kendini göstermiştir. (Beşiroğlu, 1993, s. 1,2).

Osmanlı padişahlarının Osmanlı sanat hayatında da önemli bir yeri vardır. Çok sayıda Osmanlı sultanının gerek bestekâr gerek icracı olarak musiki ile ilgilendiği biliniyor. III. Selim bu anlamda musikiye olan ilgisi ile öne çıanlardan biridir. Sultan III. Selim 18.yy'da yetişmiş, küu̧ük yaşta edebiyat ve musiki ile uğraşmaya başlamışır. Babasının ölümü üzerine başladığı kafes hayatında sanatsal ve edebi yönü

* Doktora Öğrencisi, Hacı Bayram Veli Üniversitesi, aksin.ayse@hbv.edu.tr Makalenin Gönderim Tarihi: 19.11.2020; Makalenin Kabul Tarihi: 10.12.2020 
profesyonel anlamda şekillenmiştir. En değerli eserlerini burada bestelemiş, yine birbirinden güzel makamları burada terkip etmeye başlamıştır. 28 yaşında tahta çıkan Sultan, hem musikinin icrasına hem de ilmine vâkıf olmuştur. Türk kültür yapısını korumakla beraber, yeniliklere de açık bir padişah kimliğiyle Batı Musikisi'nin bir anlamda kültürel varlığının benimsenmesi yolundaki atılan ilk adımlar, Selim’in sanata ve sanatçıya duyduğu saygının açık bir göstergesi olarak görülebilir (Çevik, 2011, s. 1).

Aynı zamanda Mevlevî olan bestekâr, hem dinî, hem de din dışı pek çok eser bestelemiştir. Kaynaklar tanbûr ve ney sazlarını ustalıkla çaldığına işaret etmektedir. III. Selim müzikolojik çalışmalarla da ilgilenmiş, kendi isteği üzerine nota yazım teorileri geliştirilmiştir. Döneminde yaşayan müzisyenleri desteklemiş, Türk Musikisi'nin gelişiminde ve gelecek nesillere aktarılmasında büyük rol oynamıştır (Çevik, 2011, s. 1).

Bu çalışma Türk Musiki tarihi için önemli bir dönem olarak görülen Selim döneminin tarih sürecinde nasıl bir rol üstlendiğinin anlaşılması ayrıca Selim'in bestelerinde görülen usul - aruz vezni ilişkisinin hangi yapı ya da yapıları kullandığının anlaşılması ve bestekârın bestecilik anlayışının irdelenmesi bakımından önemlidir.

Makalede genel hatlarıyla 2. bölümde Selim'in eğitimi ve hayatı konu edilmiştir. Ayrıca Selim'in kendisini sanatkâr olmaya iten süreçlere ve tahta çıktıktan sonraki icraatlarına değinilmiştir. 3. bölümde söz konusu dönemdeki musiki hareketleri göz önünde bulundurularak, müzikoloji alanında yapılan çalışmalardan, bestekârın diğer bestekârlara hamilik etmesi vesilesiyle beste üretme ve bestecilik furyasının oldukça aktif olmasından ve diğer sanatsal faaliyetlerden bahsedilmiştir. 4. Bölümde ise bestekârın eserleri ve vezinleri tablo halinde verilmiştir. Ayrıca bestelerin kudüm velvelesine göre dağılımı tablolar halinde gösterilmiştir.

Elde mevcut bulunan eserleri araştırıp veri toplamaya belgesel tarama denir. Bu belgeler üzerinde yapılan çalışmalar ise "Karasar Yöntemi” olarak tanımlanmaktadır (Karasar, 2002; 183). Araştırmada söz konusu yöntem ile doküman incelemesi ve eser analizi yapılarak nitel bir araştırma tekniği kullanılmıştır. Eserlerin notalarına ulaşabilmek için Devlet Korosu Nota Arşivi'ndeki (Devlet Korosu, 2020) farklı nüshalar incelenmiş, Sultan Selim'e ait 8 adet besteye ulaşılmıştır.

Eserleri incelemede güfte dağılımının daha iyi anlaşılabilmesi için usul, kudüm velvelelerine göre yazıllp şekillerin altında gösterilmiştir. Üç çizgi üzerine yazılan velvelelerde: Üst çizgi sağ zahme ile sağ kâseye vurulan darpları; alt iki çizgi ise sol kâseye vurulan darpları göstermektedir. Alt iki çizginin üstte olanı sağ zahme ile, altta olanı ise sol zahme ile vurulur.

Sağ kâse, sağ zahme

Sol kâse, sağ zahme

Sol kâse, sol zahme

Eserlerin, şekil özellikleri ve aruz vezni ilişkisi yönünden incelenmesinde Kaltakcı ve Karaman (2010) tarafından izlenen yöntem takip edilmiştir. Bu yöntemde kısa hecelerin kısa ezgilerle ve uzun hecelerin uzun ezgilerle bestelenmiş olması ve bundan mütevellit oluşan uyumun incelenmesi söz konusudur. Finale programında yazılan kudüm velvelelerinin altına veznin, darpların ve güftelerin alt alta gelecek şekilde sıralanmasıyla beraber her usule ayrı bir şablon oluşturulmuştur. Oluşturulan her usul şablonunda, güftenin heceleri uzunluk ve kısalık değerlerine göre usulün darplarının altına yazılmak suretiyle yerleştirilmektedir. Yöntemde notasyonun izlenmesini kolaylaştırmak üzere bazı müzik işaretleri ve kelimelerle ilgili uzunluklar belirli şekillerle gösterilmiştir. Bunlar;

/ : : Bir tam 4'lük es’in olduğunu gösterir.

$/ /$ : Bir 8'lik es'in olduğunu gösterir.

/// : Bir 16’llk es’in olduğunu gösterir.

... : Bir önceki hecenin devam ettiğini gösterir.

Bu çalışma, Sultân Selim’in sanatçı kişiliği ve beste formunda bestelediği 8 adet beste ile sınırlıdır.

\section{Sultan III. Selim'in Hayatı ve Sanatı}

Sultan III. Selim 24.12.1761 tarihinde doğmuş ve 28.07.1808 tarihinde vefat etmiştir. Osmanoğulları soyundan gelen Sultan III. Selim, İslam halifelerinin 20.'si ve 31. Osmanlı padişahıdır. Babası Sultan III. Mustafa, Annesi Mihr-i Şâh Sultan'dır (Öztuna, 1990, s. 279).

Anne ve babasıyla başlayan eğitim hayatı (Karal, 1942, s. 5), daha sonraki yıllarda babası tarafindan görevlendirilen seçkin ilim adamlarının hizmetiyle devam etmiştir. Babası onun sadece ilim, sanat, edebiyat 
alanında değil, devlet işlerinde de yalnız kalmaması için devlet yönetiminin bütün inceliklerini öğrenerek yetişmesine önderlik etmiştir (Özalp, 2000: c.1, s. 494).

Osmanlı İmparatorluğu XVIII. yüzylın sonlarında giderek gerilemeye başladığı dönemde yenileşme düşünceleri kafasında filizlenmeye başlayan Selim (Özalp, 2000: c.1, s. 495) 13 yaşında iken babasını kaybetmiştir. Babasının ölümü üzerine padişah olan amcası Sultan I. Abdülhamid, Selim’i saray adetlerince "kafes" denilen bir tür hapis hayatı ile tanışmasını sağlamıştır. Ancak kafes hayatının sıkı kuralları olmasına rağmen, amcasının ona şefkatle davrandığı ve yarıda kalan ilim tahsiline burada devam etmesine müsaade ettiği ifade edilmektedir. III. Selim'in edebiyat ve sanata yoğun ilgisi kafes ardında geçirdiği ylllara rastlar (Salgar, 2001, s. 15).

Osmanlı Devleti’nin varlığının korunabilmesi ve eski gücüne kavuşturulması yönünde Sultan I. Abdülhamit tarafindan çeşitli sslahat girişimleri olmuştur. Fakat bu girişimleri yetersiz bulanların Selim’in tahta geçmesini istediği rivayetleri üzerine amcası, Selim’in kafes ardındaki hayatını oldukça zorlaştırmıştır (Karal, 1942, s. 10).

III. Selim'in kafes hayatını geçirdiği ilk yıllarda saray yaşantısından, eğitiminden ve validesinin hep yanında olmasının ardından, zorlu bir döneme girmesini, her şeyden ve herkesten uzak kalmasını, kendi iç dünyasında şekillenen sanatkâr ruhunun en belirgin şekilde çıkmasını sağlamış olabileceğini belirten Salgar (2001) bestekârın en verimli zamanlarını bu dönemde geçirdiğini ileri sürmektedir. Zira musikiyle ve edebiyatla olan ilgisi ve ürettiği en kıymetli eserler bu döneme rastlamaktadır.

Amcası Sultan I. Abdülhamid'in ölümü üzerine 1789 'da III. Selim tahta çıkmıştır. Tahta çıkar çıkmaz yıllarca kafasında filizlenen yenileşme fikirlerini hayata geçirebilmek için halkın da kendisinden beklendiği girişimlerde bulunmaya başlamıştır. Avrupa'da sosyal hayatta büyük değişikler olmuş ve Fransız İhtilâli onun tahta çıktığı zamanda patlak vermiştir. Öte yandan Osmanlı topraklanı Avrupa ülkeleri ve Rusya'nın önemli hedeflerinden biri haline gelmiştir. III. Selim güvenlik kaygilarıla Yeniçeri Ocağı'nın rüşvetçi, düzensiz birliğinden bir fayda sağlanamayacağını bildiğinden yeni bir ordu kurmaya karar vermiştir (Özalp, 2000: c.1, s. 495). Nizâm-1 Cedîd adı verilen bu ordu, sadece askeri alandaki düzensizliklerin değil, devletin idari, sosyal yapısındaki bozuklukların düzeltilmesi niteliğindeki çabaların tümüne verilen addır (Gökbilgin,1988: c.9, s. 309). Bu çabalarda ilk adım, sosyal hayattaki düzensizliklerin ortadan kaldırılması ve yönetici kesimlerin sürdüğü lüks ve ihtişamlı hayatlarının devam etmemesi için alınan bir takım tedbirler ve yabancı tüketim mallarına karşı artan ilginin ortadan kaldırılması oldu. Yönetici elitlerdeki liyakat sorunları ve bu olgunun neden olduğu yönetimde huzursuzluk ve düzensizlikler bürokraside ve askeriyede Avrupa'nın siyasi, askeri idareciliği model alındığ1 reform çabalarına neden olmuştur (Salgar, 2001, ss. 1718).

III. Selim maddi kaynaklarını daha çok askeri düzenin eğitimi ve harcamaları için kullansa da sosyal alanlar için de birçok harcamalarda bulunmuştur (Karta, 2014, s. 36). Avrupa'dan hocalar getirtip Türk hocalarla birlikte Mühendishâne-i Bahrî-i Hümâyûn'u genişletti. Çağdaş bilime 1şık tutacak okul ve kütüphaneler açıı ve bazı kitapların tercümesini yaptırdı. Böylece Türk bilim ve kültürünün gelişmesine büyük katkı sağlayan Selim, ticari ve iktisadi alanlarda da önemli düzenlemeler yapmıştır (Salgar, 2001, s. 22). Türkçeye önem vermiş, şiirlerinde ve Hatt-1 Hümâyûn'larında kolay, anlaşılabilir bir dil kullanmışıır (Özalp, 2000: c.1, s. 495). Bu uğraşların yanı sıra saray bahçesinde düzenlenen gösteri ve eğlenceler, sarayın mimarisi ve düzeniyle ilgili yapılandırmalar ve bunun gibi pek çok değişiklik padişahın zevk ve ilgisinin doğal bir sonucu olarak karşımıza çıkmaktadır (Yurttadur \& Cimilli, 2015, s. 123).

Uzun ylllar tahtta kalan Sultan III. Selim, istediği yenilik hareketlerinin hepsini gerçekleştirememiş, Fransız İhtilâlinin de etkisiyle iç sorunlar daha da büyümüştür. Bu da halkın kendisine olan güvenini sarsmış, Avrupa tarzı yaşam biçimi, tutucu kesimler tarafindan yükselen eleştirilere konu olmuştur. $\mathrm{Bu}$ yenilik düşmanlığının önüne geçilememesi bir nevi Sultan III. Selim’in sonunu hazırlar niteliktedir. Kabakçı Mustafa Ayaklanması ile tahttan indirilip, katledilmiştir (Salgar, 2001, ss. 25-26-27-28).

\section{Sultan III. Selim'in Sanat1}

Osmanlı İmparatorluğu hanedanındaki bir kısım padişah ilme, musikiye, edebiyata ve birçok sanat alanına ilgi duymuş, bir kısmı da sadece ilgi duymayıp kendini sanatın içinde bulmuş ve kıymetli eserler 
bırakmıştır. Bunlardan hanedanın 28. padişahı olan III. Selim'in Türk Musikisi bestekârları arasında farklı bir yeri olduğu herkes tarafindan bilinen bir husustur (Çevik, 2011, s. 7).

Selim, genç yaşta hem devlet işleri için hazırlanmış, hem de sanatsal faaliyetlerle iştigal etmeye başlamışır. Bu yıllar "kafes" ardında geçirdiği yıllara rastlamaktadır. Zira III. Selim, burada kaldığ1 müddetçe hem babasının gerçekleştirmek istediği yenilikçi fikirleri, ileride kendisinin yapacağını planlamış, hem de musiki ve edebiyatla uğraşmaya başlamıştır (Çevik, 2011, s. 7).

Söz konusu dönem Selim'in musiki adına en verimli yıllarıdır. Küçük formda ve büyük formlarda birçok eser bestelemiş, Arazbâr-Bûselik, Dilnevâz, Evcârâ, Gerdâniye-Kürdî, Hicâzeyn, Hüzzâm-1 Cedîd, Isfâhânek-i Cedîd, Nevâ-Kürdî, Nevâ- Bûselik, Pesendîde, Rast-1 Cedîd, Sûz-i Dilârâ, Muhayyer Sünbüle, Şevkefzâ, Şevk-u Tarâb, Şevk-i Dil gibi pek çok makamı terkip etmiştir. Bu makamlardan pek çok kıymetli eser bırakmıştır. Bestelediği eserlerle bu makamların canlılığını artırarak unutulmamasını da sağlamıştır (Çevik, 2011, s. 9).

Şehzâdeliği sırasında Kırımlı Kâmil Efendi'den musiki talimine başlamış, bestekârlık gibi uzmanlık gerektiren tekniği, yine hocasından öğrenmiştir. Hatta Selim, saltanatı boyunca hocasını aynı görevinde bırakmış, padişahın II. imamı olarak saygı, itibar görmesini sağlamıştır. Selim bestekârlık eğitiminin yanı sıra dönemin ünlü tamburisi Tamburi İsak'dan tanbûr öğrenmiş ve birçok saz eseri bestelemiştir (Salgar, 2005, s. 148).

III. Selim tahtta kaldığı sürede hanedanlı̆̆ın işlerinden vakit buldukça musikiyle ilgilenmiş, kafes ardında geçirdiği yıllardaki kadar yoğun olmasa da kıymetli eserler bestelemiştir. Musiki ve sanat dallarındaki hamiliğini hiçbir zaman bırakmamış, birçok bestekârın yetişmesine vesile olmuştur (Salgar, 2001, s. 31).

Mevlevî tarikatına mensup olan III. Selim, devlet işlerinin onca ağıllığına rağmen, Mevlevîliğe ve Galip Dede'ye olan hayranlığı dolayısıyla sık sık Galip Dede'yi ziyaret etmekte ve ondan feyz almaktadır. Hatta Şeyh Galip, Galip Divanı’nda III. Selim için yazdığı 11 kasidesi, 24 tarihi, 1 terci-i bendi, bir şarkısı, 2 mesnevisi ve 6 beyiti bulunmaktadır. Buradan hareketle Galip'in Selim'e gösterdiği sevgi ve saygının son derece samimi olduğu anlaşılmaktadır (Ayvazoğlu, 1999, s. 66-67).

Şeyh Galip, eserlerinde Selim’in genelde yenilikçi yönünü vurgulamıs, onu "rûh-1 nev" yani "taze can" olarak nitelendirmiştir. Galip Dede'nin Sultan’a yazdığ kasideden iki beyit şöyledir (Dilçin, 1993, ss. 209219);

Seh Selim Han ki dehri kerrlmusdur

Mevsim-i nev-bahâr-veş bandân

Hozr irişdi bu devlete feyzi

Sebz olup sayesinde bâğ-l cihân

XIX. yüzyllda gelişen siyasi ve sosyal olaylar neticesinde Mevlevîliğin en önemli merkezleri olan Mevlevihanelerde bestekârlar, kudümzenler, neyzenlerle beraber birçok musikişinas yetişmiş, bu anlamda adeta bir konservatuvar işlevi görmüşlerdir. Edebiyatta, sanatta ve musikide Türk kültür ve sanat hayatına katkı sağlayan, günümüzde bile hala etkinliklerini koruyan önemli simaların yetişmesine katkıda bulunan bu dergâhların etkinliği, şüphesiz Osmanlı Sultanlarının desteği ve ilgisi sayesinde olduğu (Küçük, 2007, ss. 507-528) düşünüldüğünde, Sultan Selim'in bu konudaki bilinçli destek ve teşviklerinin, gelecek nesillerin daha bilinçli bir şekilde yetişmesine atılan adımların bir göstergesi olduğu şüphesizdir (Çevik. 2011, s. 10).

Musîkî çalışmalarının yanında III. Selim, İlhâmî mahlasıyla bir Divân da tertip etmiştir. Halkın zevkine ve şiir anlayışına yönelerek, sade bir Türkçe ile şïrler yazmıştır. Şiirlerinden birkaç örnek şöyledir (Özalp, 2000: c.1, s. 498):

Ey serv-i gülzâr-ı vefâ

Niçin ettin bize cefâ?

Unutuldu, hayal oldu,

Ettiğimiz. zevk u safâ

Gel gidelim, zevke edelim,

Etme bana ceur ü cefâ.

Elâ gözler mestânedir, 
Așsılkına bîgânedir,

Bilmez misin benim hâlim?

Bu tegafül cânâ nedir?

Gel gidelim, zevk edelim,

Etme bana cevr ü cefâ.

Kapuldim ben bir civâne.

Gül nibâli, nar fidâne,

Sarlsam ince meyâne,

Gel etme cevr ü cefâyn,

Sürelim zeve u safây.

Güzeldi tâze edâsı,

Kâmeti, serv-i bâlâsl,

Gönlüme düșdü sevdâst,

Gel etme cevr ü cefâyn,

Sürelim zeve u safâyz.

Yukanda örneği gösterilen şiirde görüldüğü üzere, şiirlerinde gayet sade ve samimi bir dil kullanmıştır. 18.yy. 19.yy.'lar arasında yaşayan klasik şairlerinden Nedim, Şeyh Galip, Enderunlu Vasıf, İzzet Molla gibi şairler, yazdıkları şiirlerinde halkın beğenilerini göz önünde bulundurarak oldukça sade ve basit bir dil kullanmışlardır. Milli zevkleri önemseyen bu yöneliş Selim döneminde etkin olduğu kadar kendisinden sonra gelen II. Mahmut zamanında da etkili olmuştur. (Can, 2009, s. 5). Bu da III. Selim’in sanata bakışı ile devlet işlerinin yönetimindeki yenilikçi hareketleri arasında bir paralellik olduğunun göstergesidir. Bu tavır, musikide de kendini göstermektedir (Çevik, 2011, s. 12).

III. Selim'in, Batı sanatlarıyla ilgili olarak sarayda opera, bale ve dans gösterilerini zevkle izlediklerini, bilhassa batılı dansların müziklerini hayranlıkla dinlediklerin sarayda batılı tarzda konserler verildiğini aktaran Beşiroğlu, III. Selim dönemi müzik faaliyetlerini, kendisinden önceki dönemlerde müzik faaliyetlerinin ana prensibini muhafaza etmekle beraber, yeni makam ve formlann ilavesi ile geleneksel üslubun günümüze kadar gelebilmesinde etkili olduğunu vurgulamıştır. Ayrıca, bu sürecin Selim’in hem icracı hem de bestekâr olması, dönemindeki musiki anlayışı ve bu dönemde yaşayan bestekârların musiki faaliyetlerindeki ortak birliktelik, onun tarihsel süreç içerisinde "ekol" olarak değerlendirilmesine neden olmuştur. Bu sürecin değerlendirilmesinde, sadece Sultan III. Selim'in musiki anlayışı değil, döneminde yaşayan bestekârlara verdiği destek ve bu bestekârların mûsîkî eserlerinin payı büyüktür (Beşiroğlu, 1993, ss. $15,29,30)$.

Döneminde terkip edilen Acem-Kürdî, Evcârâ, Ferahfezâ, Muhayyer-Kürdî, Sûz-i Dil, Şevkefzâ, TâhirBûselik, Neveser, Ferahnâk, Sûznâk gibi makamlarla, Türk Musikisi, en feyizli ve en doruk şöhretini yaşamıştır. Yine bu dönemde dinî musiki'deki üretkenlik, önceki döneme göre bir hayli dikkat çekici olmakla beraber, bestekârların günümüze gelen dinî formdaki eserleri, önceki dönemlere göre artış göstermektedir (Çavdaroğlu, 2009).

Musiki açısından göstermiş olduğu en reformcu tutumu, yeni makam terkiplerinin yapılması ve Türk Musikisi'nin uzun ve klasik formlarının yanı sıra, beste formlarının ve usullerinin yeni bir anlayışa göre yorumlanıp, form açısından küçülmesine vesile olmasıdır. Bu, en çok Şarkı formunda görülmektedir. III. Selim ekolünde yetişen pek çok bestekârın da Şark1 formunda pek çok eser verdiği, Selim’in sanat anlayışının diğer bestekârlara yansımış olduğunun bir göstergesi olduğu düşünülebilir. (Beşiroğlu, 1993, s. 24).

Bestelenen bu küçük formlu eserler, çeşitli şekillerde karşımıza çıkmaktadır. Bu eserlerin bir kısmı terennümsüz bir Beste veya Ağır Semâî ağıllığında olup, icrası oldukça zor, bir kısmı ise ritmik ve melodik unsurları sade ve anlaşılır bir şekilde bestelenmiş, fevkalade güzel eserlerdir. Şarkı formunu, daha sade ve kolay anlaşılabilir olarak bestelemesinin nedeni musikiyi daha geniş kitlelere yaymak ve daha popüler hale 
getirmek isteğidir. 18 kadar Şarkı bestelemiş olan III. Selim'in, popülerleşme sürecinde bu eserleri bestelerken, sanat anlayışı ve duygulara hitap edilebilirliği açısından kendinden ödün vermemiş olması ve halkın ortak duygularına tercüman olması (Salgar, 2001, ss. 40,44), eserlerinin kendinden sonraki dönemlerde de aynı feyizle, aynı ortak hislerle dinleniyor olması, kudretinin, aklının ve zekâsının bir ürünü olarak değerlendirilebilir. Bu sayede, eserleri günümüzde bile Türk Musikisi’nin başarılı örneklerinden kabul edilmekte ve halen icra edilmektedir (Çevik, 2011, s. 13).

III. Selim ekolü içinde yer alan bestekârların musiki anlayışları ve temayülleri birbirinden farklılık göstermektedir (Öztuna, 1990: c.2, s. 282). Sâdullah Ağa, Zeki Mehmed Ağa, Vardakosta Ahmed Ağa, Abdülbaki Nâsır Dede gibi bir kısım bestekârlar geleneksel tavır ve üslubu izlemiş ve bu yönde eserler vermiştir. Numan Ağa, Abdi Efendi, Rıza Efendi, Tahir Ağa gibi kimi bestekârlar da Şarkı, Tavşanca ve Köçekçe formlarında eserler vermişlerdir. Dede Efendi ve III. Selim gibi hem geleneksel anlayışı takip eden, hem de yeni form ve usullerde eserler veren bestekârlar bulunmaktadır. Bu konularda musiki anlayışlarının gösterdiği farkların yanında fasıl bestekârlığında da değişimler söz konusu olmuştur. Bir fasıl besteleneceği zaman ortak musiki tavır ve üsluba sahip, musiki birlikteliği olan ve aynı musiki fikrine sahip bestekârların birlikteliğinden doğan "ortak fasıl” besteleme geleneği yine bu dönemin belirgin özelliğidir (Beşiroğlu, 1993, ss. 23, 29).

Yenilikçi bir padişah ve bestekâr olarak, yaşadığı sürece yeniliklere açık olmuş ve bu reformcu kişiliğini yaptıkları ile paralel olarak her alanda sergilemiş olan III. Selim'in, musikideki üretkenliği ve musikiye olan katkıları oldukça büyüktür. En önemli katkılarından biri döneminde bestelenen eserlerin günümüze intikalini sağlamak amacıyla, müzikolog niteliğindeki müzisyenlere nota yazısı geliştirmeleri için teşvik etmiş olmasıdır. Bu nota yazım sistemleri ile bestelenen şâheserlerin ve terkip edilen makamlardan yapılan eserlerin notalanı, farklı form arayışlarının ifadesi olarak birçok eserin muhafazası, musikimizin zenginleştirmiş yanının ifadesi olarak günümüze kadar gelebilmiştir. Bu, Sultan III. Selim’in musiki ilmine bilinçli yaklaşımının göstergesi olarak değerlendirilebilir (Çevik, 2011, s. 14).

$\mathrm{Bu}$ nota sistemlerinden biri Hamparsum Limonciyan tarafindan Selim'in teşviki ile geliştirilmiştir ve kendi adını taşımaktadır. Bu nota sisteminin en bariz özelliği, her sese karşılık bir işareti olması ve notanın soldan sağa doğru yazılmasıdır (Öztuna, 1990: c.2, s. 113). Bu nota sistemi ile ilgili Öztuna (1990) şu bilgileri vermektedir:

"Bir sekizli şöyledir; re, bakiye diyezli re, mi, fa, bakiye diyezli fa, sol, bakiye diyezli sol, la, bakiye diyezli la, koma bemollü si, si, do, bakiye diyezli do, re. Her ses, bir takım Ermeni harflerinden ilham alınarak yapılmış harflerle gösterilir. 4'lük için iki nokta, 2'lik için tek nokta, 1'lik için uzunlamasına küçük çizgi, 8’lik için iki tane böyle çizgi, 16’lık için bir küçük yuvarlak, 32'lik için iki küçük yuvarlak kullanıllı; bunlar, ait oldukları sesin üzerine işaret edilir. Üst üste iki nokta usul çizgisi, dört köşe teşkil edecek surette konulan dört nokta da çifte çizgi hizmetini görür. Noktalı birlik ve noktalı 8'lik için de iki işaret mevcuttur. Sükût işaretleri ise, birbirine benzeyen şekillerden yapılmıştr"'(Öztuna, 1990: c.2, ss. 139-140).

Gerek nota yazısı ve gerekse nazariyat konusunda daha önceden yapılan çalışmaların yetersizliği ve eksikliğinden dolayı, Selim, Abdülbâki Nâsır Dede'ye bu hususun sonuçlanması emrini vermiş ve Abdülbâki Nâsır Dede iyi bir çalışmayı müteakiben 1794'de ilk eserini kendisine sunmuştur. Tedkik u Tabkîk adını verdiği eserinde 136 makam ve 21 usulün tarifi bulunmaktadır. Sultan III. Selim'e sunulan bu eser, Sultan'ın takdirini kazanmıştır. Yine Selim'in isteği üzerine, yeni terkip edilen makamlar da bu kitaba eklenmiş ve böylece 1795 'de kitap yeniden düzenlenmiştir (Salgar, 2001, ss. 31-32). Abdülbâki Nâsır Dede'nin yazmış olduğu bir diğer kitap ise Tabrîrîye adını taşır. Bu kitabın temelini teşkil eden temel unsur Ebced notasını yeniden yorumlamasıdır. Bugün kullandığımız sisteme kadar en iyi musiki nota yazısının Ebced Notası olduğunu öne süren Öztuna (1990), Tahrîrîye'de bu notanın izahının yapıldığını ve biri Âyîn-i Şerîf olmak üzere 4 eserin notaya alındığını belirtmiştir. Bu nota yazım sisteminin ilk sekizlisinde 18, ikincisinde 17 ses olduğunu ve bu ses sahasının yegâh ile tiz hüseyni arasında olduğunu belirtmisstir (Öztuna, 1990: c.2, s. 139).

Musiki ilmine vâkıf olmasının yanında, Mevlevîliğe olan hürmeti ve bestekârlara, dinî formda eserler üretmeleri için teşvik ve iltifat göstermesi, Selim ekolünün bir parçası niteliğindedir. Mevlevilik felsefesine ve ruhuna sahip olan bestekâr, dinî musikide de bestekârların sanat anlayışlarının yenilik ve güzelliğe açı bir yorumla doruğa ulaşmasını sağlamıştır. (Beşiroğlu, 1993, s. 29). 


\section{Sultan III. Selim'in Beste Formunda Eserlerinin Usul-Aruz Vezni İlişkisi Yönünden İncelenmesi}

Sultan III. Selim, Türk Musikisine birçok makam kazandırmıştır. Bazı kaynaklarda Sultan Selim tarafindan terkip edilen makam sayısının 14, bazılanında ise 16 olarak belirtilmiştir. Özellikle Acem Bûselik, Gerdâniye Kürdî, Nevâ Bûselik, Bâyâti Arâbân ve Evcârâ makamlarının Sultan Selim tarafindan terkip edildiği genel kabul görmekle beraber, Abdülbâki Nâsır Dede'nin Tedkik ü Tabkik isimli eserinde ve bir nazariyat kitabı olan Haşim Bey Mecmuâsı'nda bu makamların Selim'den önceki dönemlerde de var olmuş olabileceği ancak zamanla unutulmuş olduklarından ve Selim tarafindan kendi döneminde canlandırıldıklarından Selim'e atfedildikleri değerlendirilmektedir (Beşiroğlu, 1993, s. 25).

Sultan III. Selim'in elimize ulaşan 8 adet beste formunda eseri bulunmaktadır. Çalışmanın bu kısmında, bestekârın bestelerinin teknik karakterlerini göstermek amacıyla bu eserlerin notaları sunulmakta ve eserler usul-vezin ilişkisi yönünden incelenmektedir.

Sultan III. Selim'in Beste formundaki eserlerinin farklı nota arşivleri ve güfte antolojilerindeki versiyonları detaylı bir şekilde incelenerek vezinleri belirlenmiş ve buna dayanarak güftelerdeki hatalar giderilerek biçimsel olarak incelenmiştir. Bu incelemede güfte dağılımının daha iyi anlaşılabilmesi için usul, kudüm velvelelerine göre yazılıp şekillerin altında gösterilmiştir.

Tablo 1. Sultan III. Selim'in Beste Formundaki Eserlerinde Usul ve Vezin

\begin{tabular}{|c|c|c|}
\hline & Usul & Güte ve Vezin \\
\hline $\begin{array}{l}\text { Büzürg } \\
\text { Beste }\end{array}$ & Ağır Hafif & $\begin{array}{c}\text { Asskenla havâlandim bîlânelïgim gel gör } \\
\text { Mef'ûlü / Mefấîlün / Mef'ûlü / Mefấîlün (Bahr-i Hezec) }\end{array}$ \\
\hline $\begin{array}{c}\text { Evcârâ } \\
\text { Beste }\end{array}$ & Muhammes & $\begin{array}{c}\text { Mevc-i atlâs-l felekede ben bevâdan geçdim } \\
\text { Fấilâtün / Fấilâtün / Fấilâtün / Fấilün (Bahr-i Remel) }\end{array}$ \\
\hline $\begin{array}{c}\text { Pesendîde } \\
\text { Beste }\end{array}$ & Ağır Çenber & $\begin{array}{l}\text { Her ne dem sâkề elinden sâgâr-ı işret gelir } \\
\text { Fâcilâtün / Fấilâtün / Fấilâtün / Fấilün (Bahr-i Remel) }\end{array}$ \\
\hline $\begin{array}{l}\text { Rast-1 Cedîd } \\
\text { Beste }\end{array}$ & Hafif & $\begin{array}{l}\text { Cekesem o şû́bu sineye bülyâlarm gibi } \\
\text { Mef'ûlü / Fấilâtü / Mefấîlü / Fấilün (Bahr-i Muzârî) } \\
\end{array}$ \\
\hline $\begin{array}{l}\text { Sûz-i Dilârâ } \\
\text { Beste }\end{array}$ & Hafif & $\begin{array}{c}\text { Cin-i givsûsuna zencîr-i teselsül dediler } \\
\text { Fecilâtün (Fấilâtün) / Fe'ilâtün / Fe'ilâtün / Fe'ilün (Bahr-i Remel) }\end{array}$ \\
\hline $\begin{array}{l}\text { Sûz-i Dilârâ } \\
\text { Beste }\end{array}$ & $\begin{array}{l}\text { Darbeyn (Devr-i Kebîr } \\
+ \text { Berefşân) }\end{array}$ & 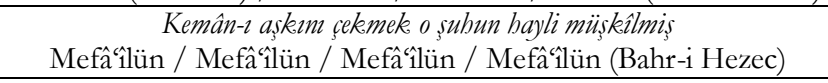 \\
\hline $\begin{array}{c}\text { Şevk-u } \\
\text { Tarâb Beste }\end{array}$ & Zencîr & $\begin{array}{c}\text { Perçem-i gül-pusunun yâdyyla feryâd eyledim } \\
\text { Fâcilâtün / Fấilâtün / Fấilâtün / Fấilün (Bahr-i Remel) }\end{array}$ \\
\hline Zâvil Beste & Ağır Çenber & 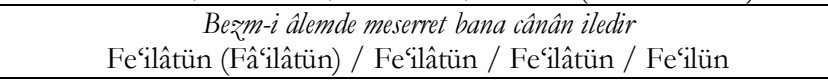 \\
\hline
\end{tabular}

Eserlerin incelenmesinde Kaltakcı ve Karaman yöntemi kullanılmıştır. Bu yöntemde eserlerin güfteleri usul çizgisinin altına yerleştirilmiştir. Hece dağılımlanı, karşılık bulduğu usul darbına göre yerleştirilerek usul-vezin incelemesi yapılmıştır.

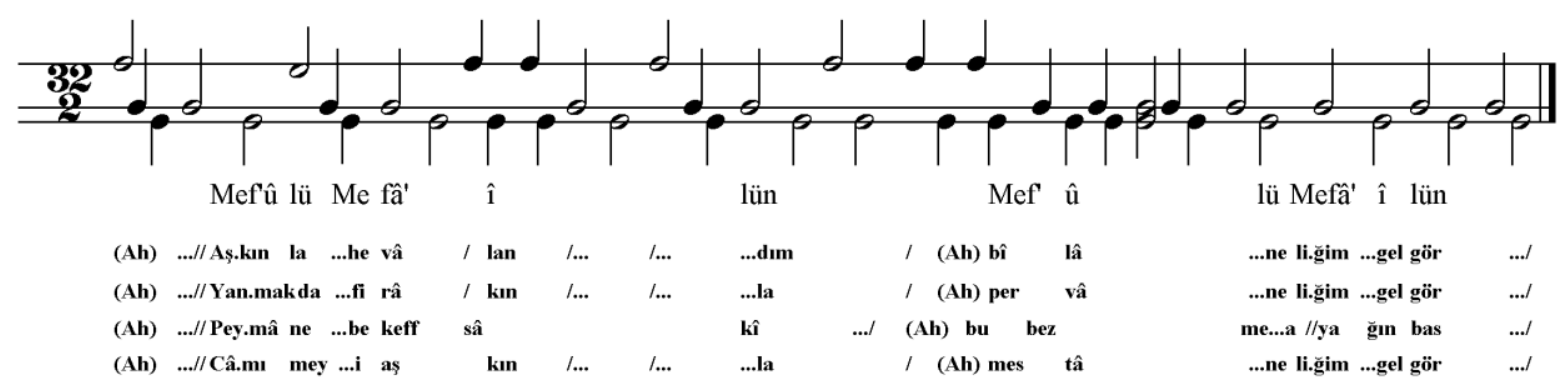

Şekil 1. Büzürg Beste'de Güftenin Ağır Hafîf Usulünün Kudüm Velvelesine Göre Dağılımı

Şekil-1'de sunulan Büzürg makamı ve Hafiff usulündeki Beste, Mef'ûlü / Mefâîllün / Mef'ûlü / Mefấîlün vezninde bestelenmiştir. Her mısrada usulün ilk darbı (Ah) hecesiyle başlamakta, güfte ise, usulün beşinci darbında başlamaktadır. Birinci, ikinci ve dördüncü mısralardaki melodiler aynı olduğundan, vezne uygunluğu görülmektedir. Üçüncü mısra ise, meyân cümlesi olduğundan bazı kelimelerin vezinle tam 
olarak uygunluğunun sağlanamadı̆̆ı görülmektedir. Üçüncü mısranın melodik farklılıklar göstermesine karşın, bütün misralarla beraber vezne uygunluğu açıkça görülmektedir.

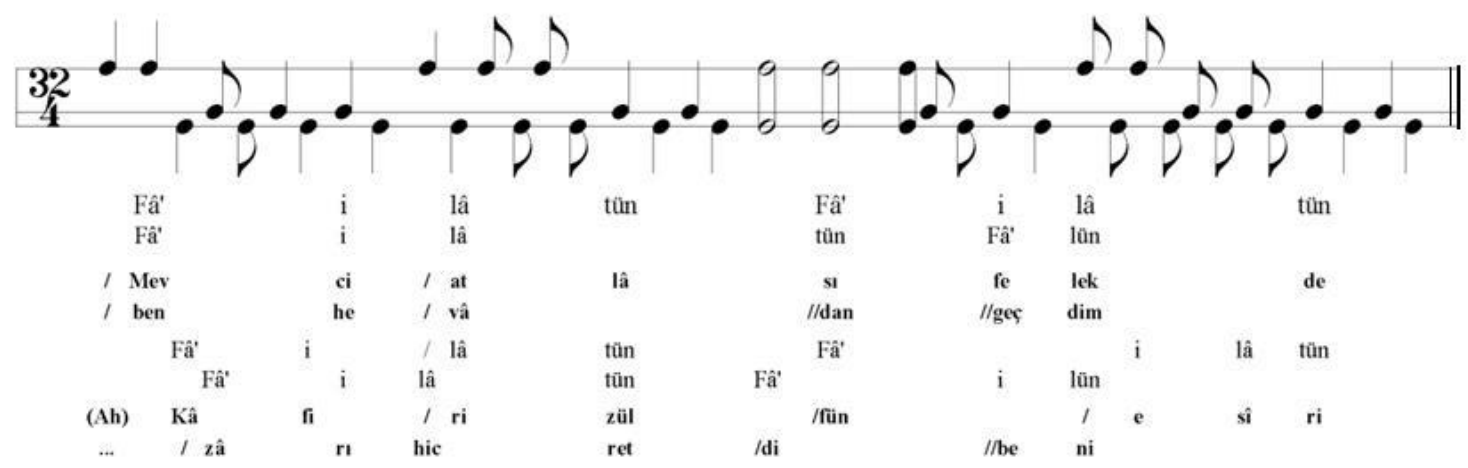

Şekil 2. Evcârâ Beste’de Güftenin Muhammes Usulünün Kudüm Velvelesine Göre Dağılımı

Şekil-2'de Evcârâ bestenin güftesinin vezne göre dağılımı sunulmaktadır. Muhammes usulündeki Beste, Fấilâtün / Fấilâtün / Fấilâtün / Fâiliün (Fâllün) vezninde bestelenmiştir. Beste iki misradan oluşmakta ve her mısra iki usul tekran ile gösterilmektedir. Birinci mısranın birinci ve ikinci usul dönüşümünde, usulün ilk darbı, dörtlük es olarak gösterilmiştir. İkinci mısradaki vezin kalıbının ise, melodik farklılıklardan dolayı farklı bir şekilde yerleşimini görmekteyiz. Bu yüzden her iki mısra için de vezin kalıbı ayrıca yazılmıştır.

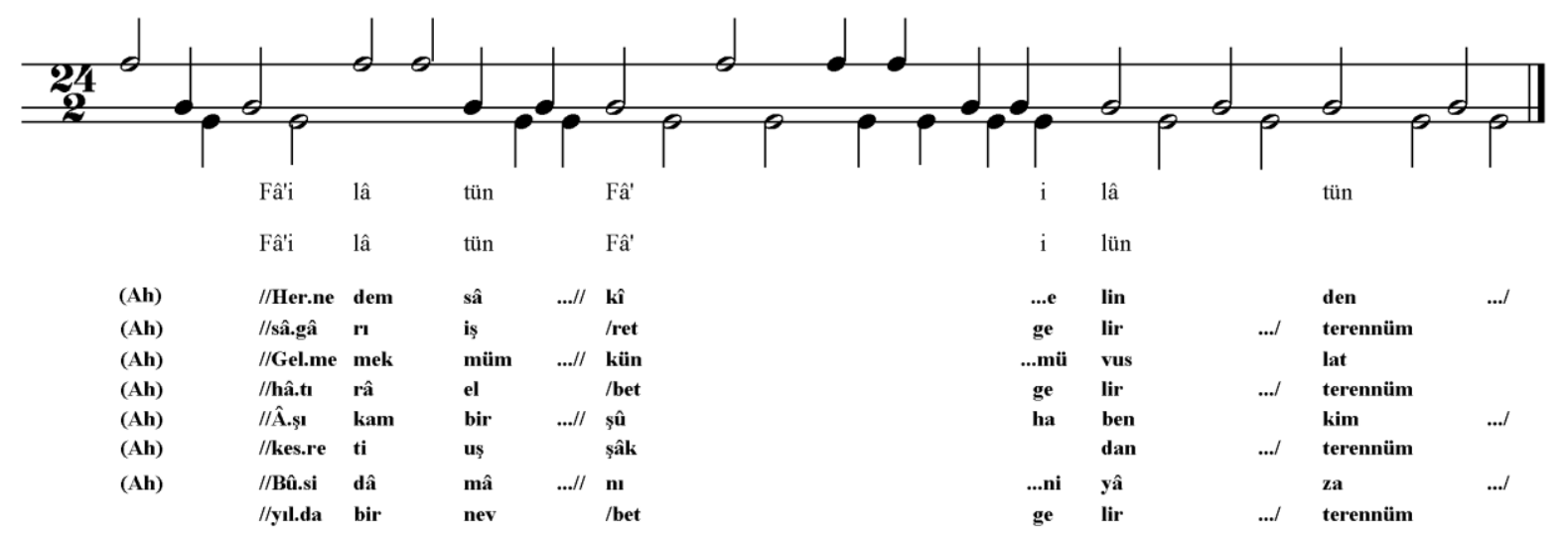

Şekil 3. Pesendîde Beste’de Güftenin Ağır Çenber Usulünün Kudüm Velvelesine Göre Dağılımı

Bestekârın Pesendîde makamında bestelediği, Çenber usulündeki Beste’si, Fấilâtün / Fấilâtün / Fấilâtün / Fấilün (Fâ'lün) vezninde bestelenmiştir (bkz. Şekil-3). Eser dört misradan oluşmuş olup, her mısra iki usul tekrarı ile gösterilmektedir. Usulün ilk darbı her mısrada (Ah) hecesiyle başlamıştur. Her usul dönümü sekizlik es’le başlamıştır. Güfte ise, usulün beşinci darbında sekizlik esle birlikte başlamış, usul bitimindeki son dört darp terennümle bitmiştir. Üçüncü mısra meyan olmasına karşın, vezne tam olarak oturtulmuştur.

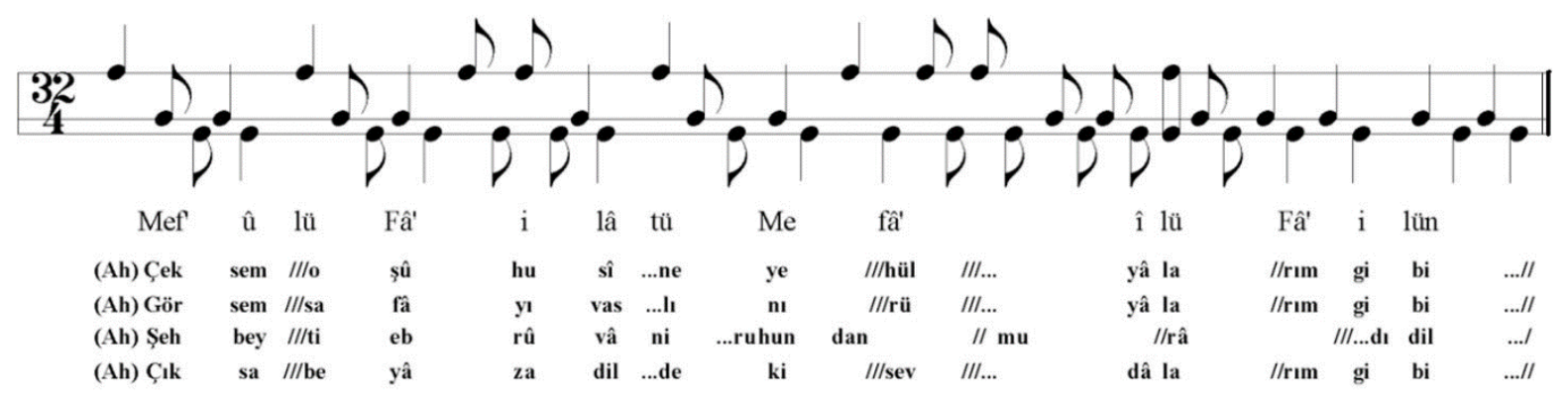

Şekil 4. Rast-1 Cedîd Beste'de Güftenin Hafîf Usulünün Kudüm Velvelesine Göre Dağılımı 
Şekil 4'te yer alan Rast-1 Cedîd makamında Hafîf usulündeki Beste'nin vezni Mef'ûlü / Fấilâtü / Mefấ îlü / Fấilün şeklindedir. Eser dört mısradan oluşmaktadır. Her misrada, usulün ilk darb1 (Ah) hecesiyle başlamaktadır. Üçüncü mısradaki güfte, melodik farklılıklardan dolayı vezne tam olarak uygunluk sağlamamaktadır.

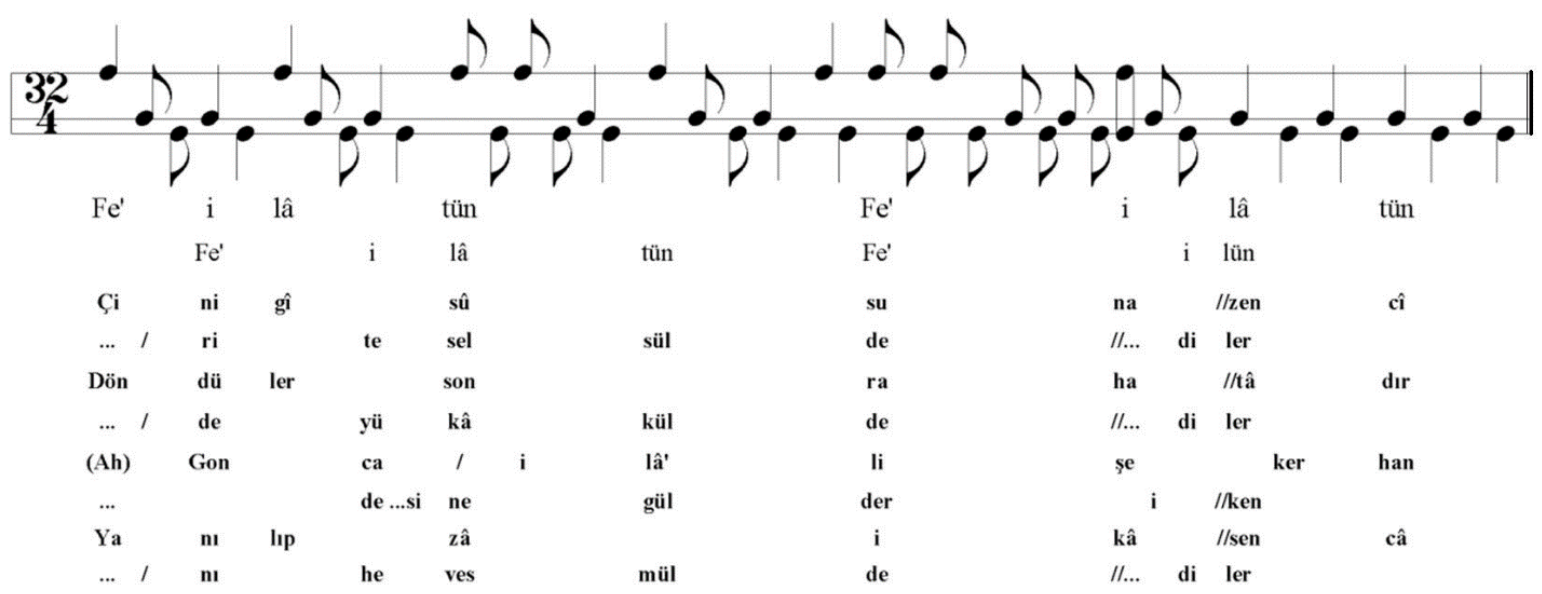

Şekil 5. Sûz-i Dilârâ Beste'de Güftenin Hafif Usulünün Kudüm Velvelesine Göre Dağılımı

Sûz-i Dilârâ makaminda ve Hafîf usulündeki Beste, Fe'ilâtün (Fấilâtün) / Fe ilâtün / Fe'ilâtün / Fe`ilün vezninde bestelenmiştir (bkz. Şekil-5). Dört mısradan oluşan güfte, iki usul tekrarı ile gösterilmiştir. Birinci, ikinci ve dördüncü mısra, usulün ilk darbıyla başlamıştır. Üçüncü mısra ise, melodik farklılıklardan dolayı, vezne tam olarak uygunluk sağlamamaktadır.
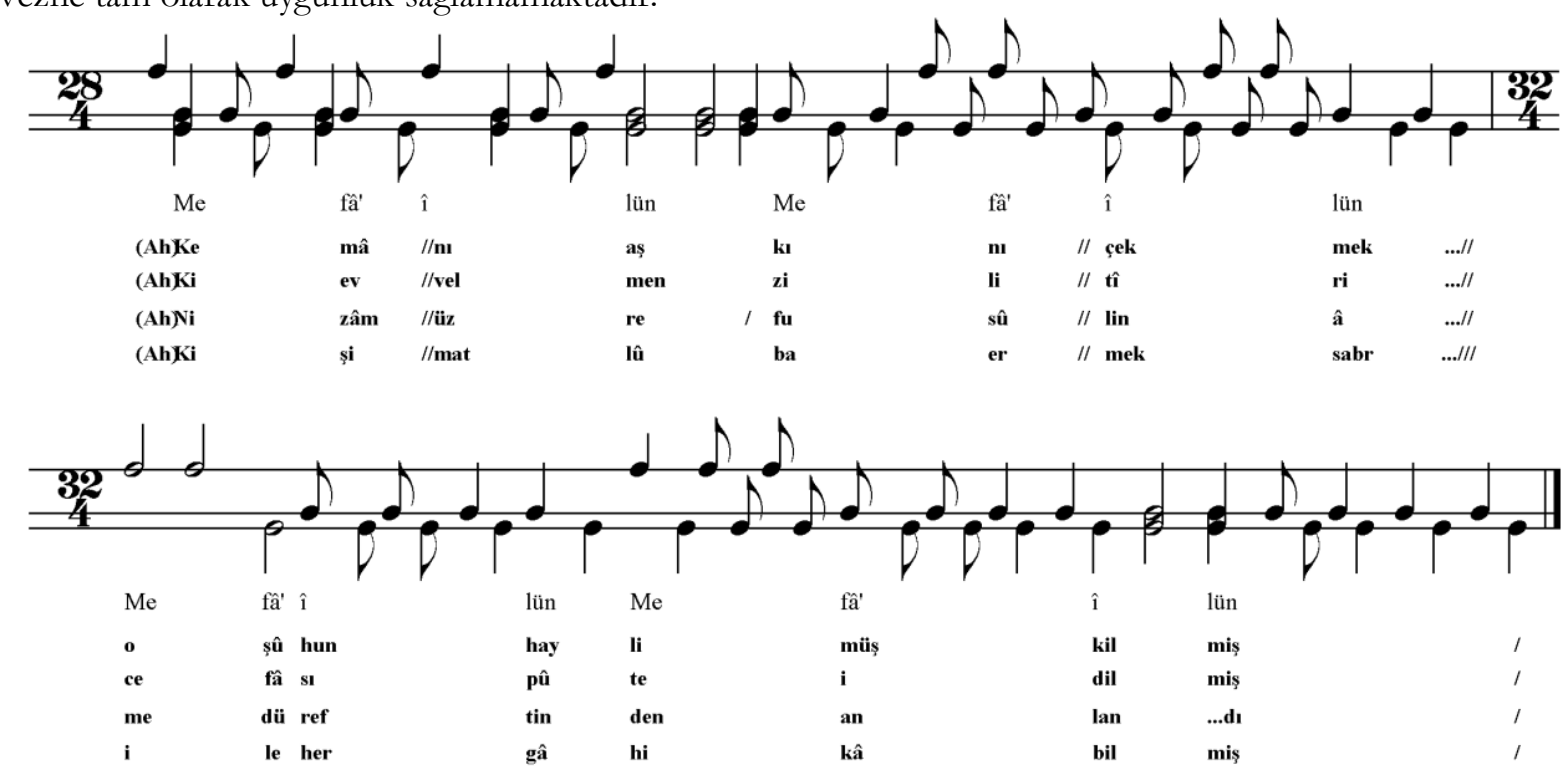

Şekil 6. Sûz-i Dilârâ Beste'de Güftenin Darbeyn (Devr-i Kebîr + Berefşân) Usulünün Kudüm Velvelesine Göre Dağılımı

Sultan III. Selim’in Sûz-i Dilârâ makamında bestelediği, Darbeyn (Devr-i Kebîr + Berefşân) usulündeki

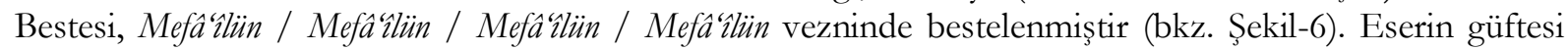
dört misradan oluşmuştur. Usulün ilk darbı (Ah) hecesiyle başlamakta, güfte ise, usulün ikinci darbında başlamaktadır. Üçüncü mısranın melodik farklılıklar göstermesine karşın, bütün mısralarla beraber vezne uygunluğu açıkça görülmektedir. 

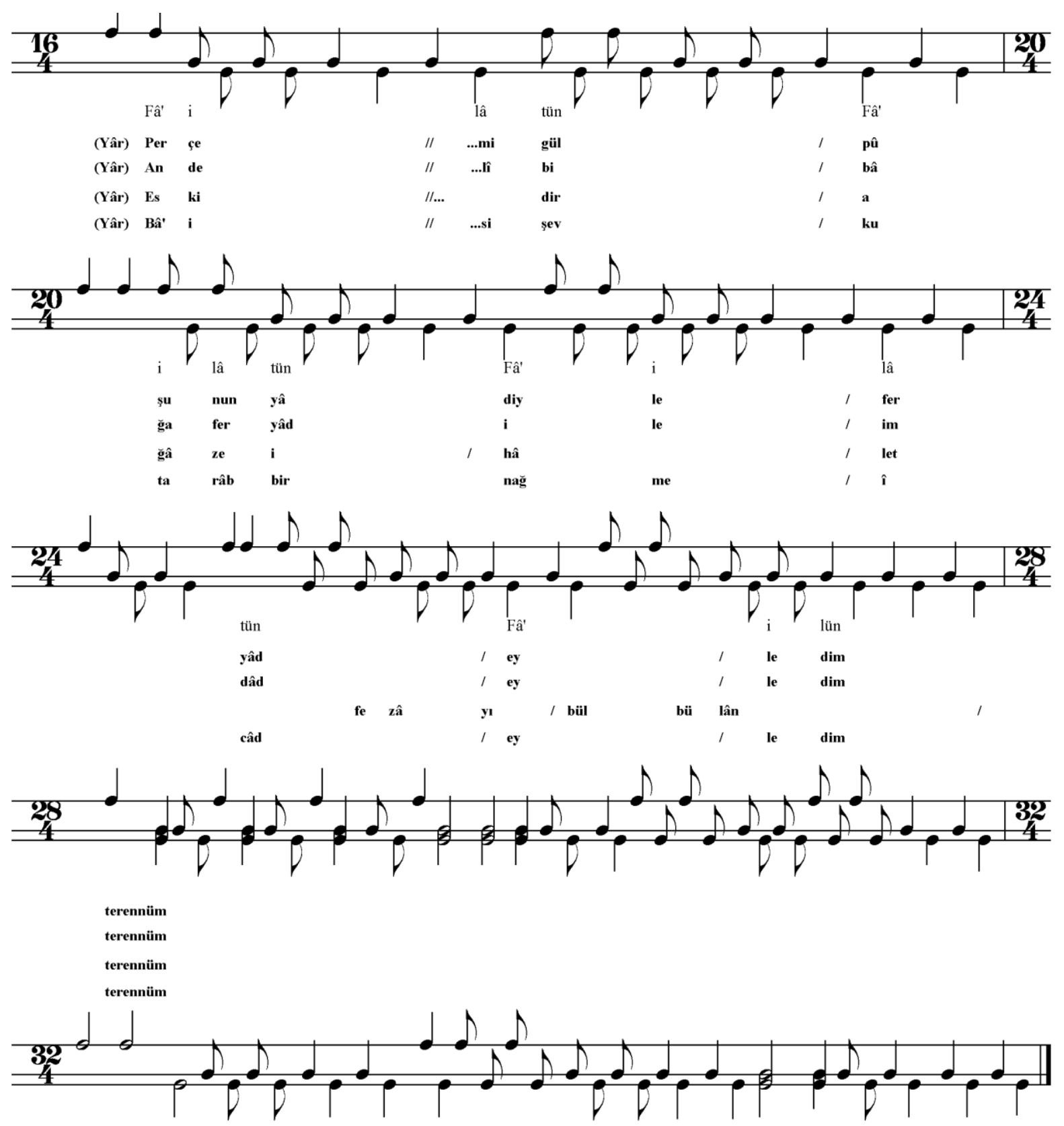

Şekil 7. Şevk-u Tarâb Beste'de Güftenin Zencîr Usulünün Kudüm Velvelesine Göre Dağllımı

Şevk-u Tarâb makamında bestelenmiş olan Zencîr usulündeki Beste, Fấilâtün / Fấilâtün / Fấilâtün / Fấilïn veznindedir (bkz. Şekil-7). Usulün ilk darbı, (Yâr) kelimesiyle başlamaktadır. Dört mısradan oluşan güfte, usulün ikinci darbında başmaktadır. Birinci, ikinci ve dördüncü mısralar melodileri aynı olduğundan vezne uygundur. Üçüncü mısra ise meyan olduğu için vezne tam olarak uygunluk göstermemektedir. 


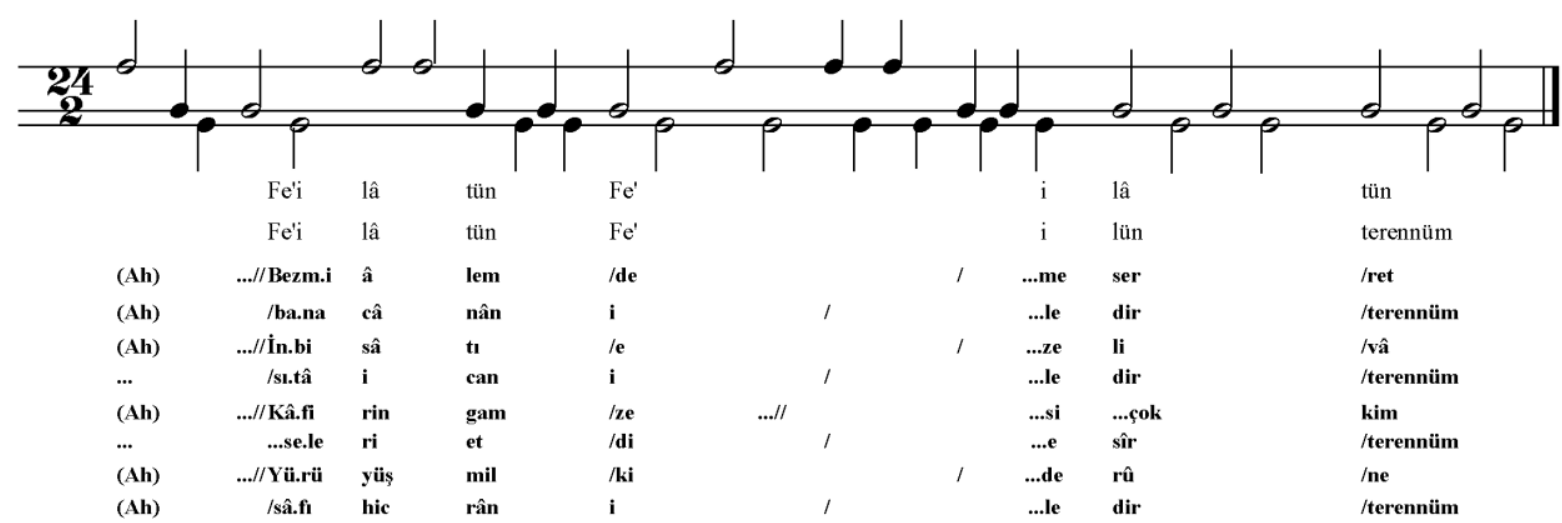

Şekil 8. Zâvil Beste’de Güftenin Ağır Çenber Usulünün Kudüm Velvelesine Göre Dağılımı

Şekil 8'de sunulan Zâvil Beste, Ağır Çenber usulünde ve Feílatün (Fâilâtün) / Fe'ilâtün / Fe'ilâtün / Fe ílïn vezninde bestelenmiștir. Güftesi dört mısradan oluşan eser, iki usul tekrartyla gösterilmektedir. Usulün ilk darbı (Ah) hecesiyle başlamış, güfte ise, usulün beşinci darbında başlamıştır. Üçüncü mısrada, melodik farlılıklar olmasına rağmen, bütün mısralarla beraber vezne uygunluğu açıkça görülmektedir.

\section{Sonuç}

Bestekârnn beste formundaki eserleri incelendiğinde, çoğu eserinin birinci, ikinci ve dördüncü mısralarındaki güfteler aynı darp ve kalıplara uygun bir şekilde yerleştirilmiştir. Bununla beraber üçüncü mısradaki hece dağılımları farkllılk arz etmektedir. Fakat birinci, ikinci, üçüncü ve dördüncü mısralarda hece dağılımını aynı şekilde yerleştirdiği bestesi de mevcuttur. Buradan da bestekârın bestelerinde tek bir kalıp kullanmama ve aynı şekil yapmamayı tercih etmesi, eserlerin durağanlıktan kurtulup, yeni arayışlar içerisine girmek istemesi düşüncesinden kaynaklandığ sonucunu akla getirmektedir. Başka bir teori de vezin kusurlarından dolayı söz konusu dağılımların farklılık arz ettiğidir.

Sultan Selim'in Büzürg, Rast-1 Cedîd ve Sûz-i Dilârâ makamlannda bestelediği, Hafif usulündeki eserlerine bakıldığında, Büzürg ve Sûz-i Dilârâ makamlarındaki eserlerin, darp ve hece dağılımlarının birbirine benzerliği dikkat çekmektedir. Sûz-i Dilârâ makamında bestelediği eser ise, yukarıda bahsi geçen makamların usul-vezin ilişkisine benzemekle beraber, tek farklılığı, eserin iki usul tekrarı ile bestelenmiş olmasıdır. Rast-1 Cedîd makamında ve Hafiff usulünde bestelediği eserin 1. 2. ve 4. mısralarındaki hece dağılımlarının uygunluğu tespit edilmiştir. Meyanhane kısmında ise söz konusu darp ve hece dağılımlanında farkllikklar görülmektedir.

Sultan Selim'in Pesendîde ve Zâvil makamında bestelediği, Ağır Çenber usulündeki eserlerinin darp ve hece dağılımları benzerlik göstermektedir. Buradan, bestekârın aynı usulde bestelemiş olduğu eserlerinin hece dağılımlarını benzer bir kalıp içerisinde kullandığı ortaya çıkmaktadır.

Bestekârın eserlerinde görülen usul-aruz vezni ilişkisini tam manasıyla anlamak için bütün eserlerinin bu ilişki içerisinde değerlendirilmesi yerinde olacaktır.

Güftelerin vezin tespiti esnasında, bazı güftelerin zaman içerisinde değişerek günümüze ulaştı̆̆1 anlaşıldığından, güftelerdeki yanlışlıklar mümkün olduğunca düzeltilerek yazılmıştır. Buna rağmen tüm eserlerinin güftelerinin detaylı bir şekilde elden geçirilmesi, notaya alınması söz konusu beste formunun ve bestekârın beste anlayışının daha iyi değerlendirilmesine ve anlaşılmasına katkı sağlayacaktır.

\section{Extended Abstract}

This study aims to reveal the impact on Turkish music tradition and the position of Sultan Selim III, who was a music lover, composer, and performer who left his mark on Turkish music history, in Turkish Classical Music and to examine his works in the form of Beste in terms of the harmony of lyrics and the relationship of the pattern and the aruz rhythm.

In addition to his reformist character in administration and military, Ottoman Sultan Selim III also came to the fore with his artistic personality and composer personality at his time that could be called the 
"Selim Period" in Turkish music history and his influence on the art of the period. He contributed to the creation of a productive period in Turkish music with the works he composed and the maqams he compounded and the influence of the artists of the period, as well as his patronage of art. Some of his compositions and maqams are performed in the repertory of Turkish classical music today.

In this study, first of all, Selim III's position as a musician and composer in Turkish music and musical movements in his time have been investigated. Later, his works in written the form Beste were analyzed in terms of the pattern - the aruz rhythm. For the purpose of analysis, first, the works were rewritten in Finale software, then the distribution of the syllables in the lyrics was made using the method velvele. Each syllable in the line is placed according to these strokes. The pattern templates were written on three lines in the computer environment and the lyrics of the works were distributed according to their note values.

The first part of the study evaluates "Selim period", which is seen as an important period in the history of Turkish Music in many sources, Selim III's actions, his artistic personality, and the art movements in his period were mentioned. Having an innovative spirit, Selim III is known as the pioneer of the westernization movements due to his admiration for the western arts as well as the state administration. The Nizam-i Jedid (New Order) reforms, which was a series of reforms initiated by Selim III during the late 18th and early 19th centuries are seen as a reflection of his admiration. During this period, the westernization movements had emerged in Turkish Music. Selim III also pioneered in this regard.

It is known that many Ottoman sultans were interested in music both as composers and performers. Selim III is one of the prominent ones with his interest in music. Selim III started to deal with literature and music at a young age. The "cage life" he was exposed to upon the death of his father had an impact on his artistic side. He composed his most valuable works and started to compound beautiful maqams here. Sultan, who ascended the throne at the age of 28 , had a knowledge of both the performance and science of music. While preserving the Turkish cultural structure, the first steps taken towards the adoption of the cultural existence of western music with a sultan identity who open to innovations can be seen as a clear indicator of Selim's respect for art and the artist.

The second part of the study examines Selim III's works composed in the form of Beste in terms of the relationship of pattern and the aruz rhythm. First, the different versions of the notes of the works have been brought together to examine comparatively against mistakes. They were corrected and rewritten in the computer environment using Finale software. While examining the lyrics of the works, their aruz measures were determined and therefore the spelling mistakes in the lyrics were corrected as much as possible. In the stage of examining the works in terms of the pattern and the aruz rhythm, the velvele of the pattern used in the works was taken into consideration to make the distribution of syllables in the lyrics easier to understand. Each syllable in the line is placed according to these strokes. The pattern templates were written on three lines in the computer environment and the lyrics of the works were distributed according to their note values.

It is thought that the relationship between music and literature is important to see whether there is a conscious relationship between lyrics and the aruz rhythm. Accordingly, in this study, it was investigated whether the use of the pattern and the aruz rhythm in Selim III's Bestes was composed based on a certain technique. The research findings show that the relationship between the pattern and the aruz rhythm in the composer's Bestes is mostly compatible with zeminhâne, while the parts meyan have different structures.

\section{Kaynakça}

Ayvazoğlu, B. (1999). Kuğunun son şarkısı, İstanbul: Ötüken Yayınları.

Beşiroğlu, Ș. Ş. (1993). III. Selim döneminin müzik ve müzisyenler açısından incelenmesi. Sanatta yeterlilik tezi. İstanbul Teknik Üniversitesi Sosyal Bilimler Enstitüsü, İstanbul.

Can, H. (2009). 19. yüzynl Türk saz sïirinde mubtevâ. Yayımlanmamış yüksek lisans tezi. Süleyman Demirel Üniversitesi Sosyal Bilimler Enstitüsü, Isparta.

Çavdaroğlu, S. Z. (2009) III. Selim devrinde musiki hayatından kesitler (1789-1807). Musiki Dergisi. www.musikidergisi.net. [Erişim Tarihi: 21.03.2020].

Çevik Aksın, A. E. (2011). Sultan III. Selim’in beste formundaki eserlerinin usul- aruz vezni ilişkisi yönünden incelenmesi. Yayımlanmamış yüksek lisans tezi. Selçuk Üniversitesi Sosyal Bilimler Enstitüsü, Konya. 
Devlet Korosu (2020). Nota Arşivi http://www.devletkorosu.com/. (Erişim Tarihi: 24 Aralık 2020).

Dilçin, C. (1993). Şeyh Galip in şiirlerinde III. Selim ve Nizam-1 Cedit, Türkoloji Dergisi, 11(1), 209219. doi: 10.1501/Trkol_0000000155

Gökbilgin, T. (1988). Nizâm-1 Cedîd. İslam Ansiklopedisi (cilt: 9, s. 309). Ankara: Milli Eğitim Bakanlığ1

Kaltakc1, M.Y. ve Karaman, S. (2010). İhsan Raif Hanım'n üç Türk müziği bestekârı tarafindan bestelenen şiirinin incelenmesi. 3. Uluslararası Bir Bilim Kategorisi Olarak Kadın: Edebiyat, Dil, Kültür ve Sanat Çalıs̆malarnda Kadnn Semposyumu içinde (ss. 135-146). Selçuk Üniversitesi Dilek Sabanc1 Devlet Konservatuvar1, Konya/Türkiye, 28-30 Nisan 2010.

Karal, E. Z. (1942). Selim III.'ün Hattı-ı Hümâyûnlar. Ankara: T.T.K. Basımevi.

Karasar, N. (2002). Bilimsel Arastırma Yöntemi, Ankara: Nobel Akademik Yayınları.

Karta, N. (2014). Sultan III. Selim döneminde Osmanlı İmparatorluğu'nun ekonomik durumu ve alınan tedbirler. Iğdir Üniversitesi Sosyal Bilimler Dergisi, 6: 21-50.

Küçük, S. (2007). İstanbul mevlevîhânelerinin Türk sanat ve edebiyat halkına katkıları (XIX. Asır). Türk Kültuirü, Edebiyatı ve Sanatında Mevlana ve Mevlevilile - Bildiriler içinde (ss. 507-528). Sümam Yayınları.

Özalp, M. N. (2000). Türk Musikisi Taribi: I ve II. İstanbul: Milli Eğitim Bakanlğg1 Yayınlar1.

Öztuna, Y. (1990). Büyü̈k Türk Musikisi Ansiklopedisi: I ve II. Ankara: Kültür Bakanlığ1 Yayınlan1,

Salgar, M. F. (2005). 50 Türk Müriğg Bestekârr, İstanbul: Ötüken Yayınlanı.

Salgar, M. F. (2001). III. Selim: Hayat, Sanatı, Eserleri. İstanbul: Ötüken Yayınları

Yurttadur, O. ve Cimilli, H. C. (2015). III. Selim döneminde Osmanlı Sarayı'ndaki kültürel hayatın sanat ve mimarideki Etkileri. Kalemisi Dergisi, 3(5): 121-146.

http://www.devletkorosu.com/. [Erişim Tarihi: 24 Aralık 2020]. 